\title{
Participation of Smallholder Farmers in Formal Credit Program in Dembecha District, Ethiopia
}

\author{
Abebaw Abebe \\ Raya University, college of Agriculture and natural resource, Department of Agricultural Economics
}

\begin{abstract}
In Ethiopia and elsewhere in developing countries adoption of agricultural technology, agricultural productivity and commercialization of the smallholder farmers are mainly depend upon accessibility of rural finance. This study assessed factors affecting use of formal credit by smallholder farmers in Dembecha district, Ethiopia. A systematic random sample of 200 households was drawn from four purposively selected kebeles. Descriptive statistics, inferential statistics and binary logistic regression model were used to analyze the data. The study concluded that farmers living closer to credit institution, who are more educated and well trained have a greater tendency to use formal credit. Therefore, the credit institution has to be increasing its branches and rural credit satellites so that this will decrease the farmer's opportunity cost of time. Besides, regularly monitoring and evaluation on how the customer's use their credit is also essential.
\end{abstract}

Keywords: Formal, Credit, participation, smallholder, Ethiopia

DOI: $10.7176 / \mathrm{JESD} / 11-15-05$

Publication date:August $31^{\text {st }} 2020$

\section{INTRODUCTION}

Agriculture plays a significant role in reducing poverty and serves as an important engine for growth in developing countries (Abebaw and Yared, 2018). Small family farms (smallholder farmers) dominate rural landscapes across the developing world, accounting for up to $80 \%$ of food produced in Asia and sub-Saharan Africa, while supporting livelihoods of up to 2.5 billion people (IFAD, 2016). The same source indicated that, these farmers face longstanding barriers to accessing technology, credit, knowledge and markets.

In subsistence agriculture and low-income countries like Ethiopia, where smallholder farming dominates the overall national economy, smallholder farmers dominate 95 percent of the total cultivated area and produce over 95 percent of the national crop production (CSA, 2018). However, smallholder farmers face severe shortage of financial resources to purchase productive agricultural inputs. The prices of inputs rise very rapidly every year. Consequently, the hope of the subsistence farmers on financial institutions for credit has become substantially higher times (Milion et al., 2012).

In Ethiopia and elsewhere in developing countries adoption of agricultural technology and commercialization are mainly depend on financial resource (Gizachew, 2017). Agricultural productivity of the smallholder farmers are largely depends on accessibility of rural finance and credit facility (Sophiya et al., 2012). Besides, it can mainly considered as significant role in reducing and eradicate poverty through utilization of improved technologies, production intensification and participation to market (Ibrahim and Bahur, 2013; Ololade and Olagunju, 2013). Access to agricultural credit makes conventional agriculture more productive through the purchase of modern agricultural machineries and other agricultural inputs (Deresse and Zerihun, 2018).

Rural farmers in Ethiopia are mainly accessing formal credit from Microfinance Institution (MIFs). The Association of Ethiopian Microfinance Institutions (AEMFI) was formed as a non-for-profit, non-governmental association of the Ethiopian microfinance institutions as defined by Proclamation No. 40/1996 under which microfinance institutions in Ethiopia are regulated by the national bank of Ethiopia. Regionally, AEMFI is the strongest of the country level networks in Africa. These institutions are primarily stand for smallholder farmers. There are 35 MFIs operating in Ethiopia, serving over 15 million clients. Due to their focus on clients at the base of the pyramid and the financially excluded, the MFIs have the potential to make significant contributions towards the national economic growth and financial inclusion.

In Ethiopia even though microfinance programs have been considered increasingly as important safety nets of the poor, knowledge about the achievements of these strategies remains only partial and limited, generally in the case of rural setting (Dilayehu, 2014). There are factors which make rural households not to access financial services that emanate from both supply and demand side. Identifying those factors is very imperative for policy interventions regarding to financial market.

In general in Ethiopia and particularly in study area most of the farmers borrowed money from informal private lenders. The private informal lenders lend credit at high interest rate, have not a legal license and it highly sacked the farmers. These informal lending harms the farmers and even has negative impact for all over economic system. There are only a small number of farmers which are formal credit user. Since access to institutional finance is very limited, the majority of the poor are forced to search financial services through informal channels (Assifaw and Adeba, 2016). Hence, understanding what factors determining farmer's participation from formal credit using 
is very crucial for credit related policy intervention, targeting of the policy makers in intervening credit related agenda on that area and check and balance the effectiveness of the credit institutions. Therefore, this study filled this gap and answered the following research questions. What are the factors which determine access to credit from formal credit institution? For what purpose smallholder farmers borrow money?

The objectives of the study were;

- To identify the factors affecting farmer's credit access from formal credit institution

- To analyze the purpose of credit in study area

\section{Methodology}

\section{Description of study area}

Site of the study Dembecha woreda is one of the 15 woredas (districts) of the west Gojjam zone of Amhara Region, Ethiopia. The district town Dembecha is situated $205 \mathrm{kms}$ and $349 \mathrm{kms}$ from Bahirdar and Addis Ababa, respectively. Dembecha woreda has 29 kebeles, 27 rural and 2 urban. The livelihood system of the population depends upon agriculture that is characterized by mixed farming systems. Teff, maize, wheat, barley and millet are the most widely cultivated crops in the district.

\section{Data Types and Sources}

Qualitative and quantitative data were collected to answer the objectives of the study. Data about different personal characteristics, institutional and socio-economic factors that determined credit use were collected. Primary and secondary data were used. Primary data were collected from primary sources from respondents. On the other hand, secondary data were gathered from the zone and district agriculture officers, books, journals.

\section{Method of Data Collection}

To collect data for the research, an interview schedule was used. Once the interview schedule was prepared, enumerators were recruited and they collected data from the selected respondents. Before the actual data collection took place 12 non sample farmers were selected randomly for pretest.

\section{Sampling Techniques and Sample Size}

A multi stage sampling technique was used to select sample households. In first stage Dembecha district has been selected due to high agriculture production potential. In second stage four kebeles were selected purposively from total 27 rural kebeles of Dembecha district and finally, the actual respondents were selected using systematic random sampling followed by probability proportional to size. Sampling size was determined using the formula given by (Yamane, 1967).

$$
\begin{gathered}
\mathrm{n}=\frac{\mathrm{N}}{1+\mathrm{N}\left(\mathrm{e}^{2}\right)} \\
\mathrm{n}=\frac{9850}{1+9850\left(0.07^{2}\right)}=200
\end{gathered}
$$

\section{Method of Data Analysis}

The data was analyzed by descriptive statistics such as mean standard deviation, percentage and frequency. In addition, inferential statistics, chi-square and t- test were used. To analyze the core objective factors affecting formal credit use binary logit model was used. It can be specified as follows (Gujarati, 1995);

$$
\begin{gathered}
P i=E(Y=f / x)=1 \ldots \text { (1) } \\
P i=E\left(Y=1 /_{X}\right)=\frac{1}{1+e^{-\left(\beta_{0}+\beta_{1} x_{1} \ldots \ldots \beta_{n} x_{n}\right)}} \ldots \ldots \ldots \text { (2) } \\
\text { For ease of exposition, we write (2) as:- } \\
P i=\frac{1}{1+e^{-z i}} \quad \ldots \ldots \ldots \ldots \ldots \ldots \ldots \ldots \text { (3) }
\end{gathered}
$$

The probability that a given respondent is credit user by (2) while, the probability for not to be ICT user is:-

$$
1-P i=\frac{1}{1+e^{z i}}
$$

Therefore, we can write as:

$\frac{P i}{1-P i}=\frac{1+e^{Z i}}{1+e^{-Z i}}$

Now $\left(\frac{P i}{1-P i}\right)$ is the ratio of the probability that a respondent is credit user to the probability that she/he will be nonuser.

Finally, taking of the natural log of equation (5) we obtain:

$L i=\ln \left[\frac{P i}{1-P i}\right]=Z i=\beta_{0}+\beta_{1} X_{1}+\beta_{2} X_{2}+\ldots . \beta_{n} X_{n}$ 
Where $P i=$ is the probability of the respondent to be credit user?

$1-P i=$ is the probability of the respondent to be nonuser

$Z i=$ is a function of $\mathrm{n}$ explanatory variables $(\mathrm{x})$ which is also expressed as:

$Z i=\beta_{0}+\beta_{1} X_{1}+\beta_{2} X_{2}+\ldots \beta_{n} X_{n}$

$\beta_{0}=$ is an intercept

$\beta_{1}, \beta_{2} \ldots \beta_{n}$ Slopes of the equation in the model

$L i=$ is $\log$ of the odds ratio

$X i=$ is vector of relevant household characteristics

If the disturbance term $\left(U_{i}\right)$ is introduced, the logit model becomes:

$Z i=\beta_{0}+\beta_{1} X_{1}+\beta_{2} X_{2}+\ldots . \beta_{n} X_{n}+U i \ldots$ (8)

Multicollinearity among the independent variables was checked before using them for model analysis. Variance Inflation Factor (VIF) was used for testing the association between the continuous variables and Contingency Coefficient (CC) was computed for dummy variables. The types and its effect on the dependant variable of the hypothesized variables are depicted in table 1 below.

Table1. Types and hypothesized of variables

\begin{tabular}{lllc}
\hline Variables & Description & \multicolumn{1}{c}{ Types } & $\begin{array}{c}\text { Expect effect } \\
\text { on outcome }\end{array}$ \\
CREUSE & Credit use decision & Dummy & \\
\hline SEX & Sex of the household head & Dummy & $+/-$ \\
AGE & Age of the Household Head & Continuous & + \\
YEAEDU & Education of household head & Continuous & + \\
LANDSIZ & Land size in hectare & Continuous & + \\
INCOME & Annual income & Continuous & + \\
DISTMT & Distance to market & Continuous & - \\
DISINS & Distance to institution & Continuous & - \\
EXTCON & Extension contact & Dummy & - \\
PARTRIN & Credit related training & Dummy & + \\
TLU & Number of livestock & Continuous & + \\
& & & \\
\hline
\end{tabular}

\section{Result and Discussion}

From the total sample of 200 household's 84(44.2\%) households was formal credit users from Amhara Credit and Saving Share Company (ACSSC) in Dembecha branch and the other 116 (55.8\%) households were noncredit users. The mean age of credit users and non users were 47.19 and 36.48 respectively. The mean land size of credit user and non user were 1.54 hectare and 1.06 hectare respectively. T-test result reveled that there were statistical significance difference between age, land size, livestock and annual on- farm income between credit users and non users as depicted in Table 2.

Table 2.Descriptive Statistics of continuous variables on credit use status

\begin{tabular}{|c|c|c|c|c|}
\hline Variables & $\begin{array}{l}\text { Total(200) } \\
\operatorname{Max}(\min )\end{array}$ & $\begin{array}{l}\text { User(84) } \\
\text { Mean(SD) }\end{array}$ & $\begin{array}{l}\text { Non-user(116) } \\
\text { Mean (SD) }\end{array}$ & t-value \\
\hline Age & $73(25)$ & $36.48(6.36)$ & $47.19(10.7)$ & $-6.24 * * *$ \\
\hline Family size & $10(0)$ & $5.14(2.2)$ & $4.58(1.97)$ & 1.27 \\
\hline Land size (hacta) & $3.50(0.25)$ & $1.54(0.84)$ & $1.06(0.55)$ & $3.34 * *$ \\
\hline Livestock (TLU) & $1.97(1.17)$ & $3.73(1.22)$ & $2.73(1.9)$ & $7.1 * * *$ \\
\hline Income & $21500(2500)$ & $10100(2533)$ & $9517(4936)$ & $-0.696 * *$ \\
\hline Age & $73(25)$ & $36.48(6.36)$ & $47.19(10.7)$ & $-6.24 * * *$ \\
\hline
\end{tabular}

Source: survey data $* * *$ and $* *$ Significant $\mathrm{P}<0.01$ and $\mathrm{p}<0.05$

The sample was composed of both male and female-headed households. As showed in table 2, of the total 200 sample household heads, 177(88.5) were male household heads and 23(11.5) were female household heads. About 68(34\%) and 16(8\%) of the users were male and female-headed households, respectively, while 109(54.5\%) and $7(3.5 \%)$ of non users were male and female-headed households, respectively. The proportion difference tests in terms of sex between the two groups were statistically significant at less than $5 \%$ probability level as indicated in table 3. 
Table 3. Descriptive statistics of categorical variables

\begin{tabular}{|c|c|c|c|c|c|}
\hline Variables & Categories & Total(200) & User(84) & Non-user(116) & Chi-value \\
\hline \multirow[t]{2}{*}{ Sex } & Male & $177(88.5)$ & $68(34)$ & $109(54.5)$ & \multirow[t]{2}{*}{$4.1 * *$} \\
\hline & Female & $23(11.5)$ & $16(8)$ & $7(3.5)$ & \\
\hline \multirow{4}{*}{$\begin{array}{l}\text { Participation of } \\
\text { credit training } \\
\text { Access to extension }\end{array}$} & Yes & $98(49)$ & $64(32)$ & $34(17)$ & \multirow[t]{2}{*}{$23.6^{* * *}$} \\
\hline & No & $102(51)$ & $20(10)$ & $82(41)$ & \\
\hline & Yes & $129(64.5)$ & $70(35)$ & $59(29.5)$ & $2.44^{*}$ \\
\hline & No & $71(35.5)$ & $14(7)$ & $57(28.5)$ & \\
\hline
\end{tabular}

Approximately half of the sample respondents were participated in credit relating trainings. Relatively, credit users $64(32 \%)$ were more participated in credit trainings than non users $34(17 \%)$. The difference between the users and non users by participation of trainings was statistically significant (table 3 ).

About 129(64.5) sample households were participated in extension contact and other remaining 71(35.5\%) sample farmers were not participated. More credit users had extension contact compare to non users. The difference between the users and non users by extension contact was statistically significant as showed in table 3 .

\section{Purpose of credit}

As table above indicated, majority of sample respondents responded that they borrowed money to purchase inputs like fertilizer, seed, daily laborer and pesticide. To purchase livestock (draft oxen, for fattening, poultry etc.) and for other household expense such as education, health and other emergency expense were the second and third purpose of credit for sample farm households as depicted in table 4.

Table 4. Purpose of credit

\begin{tabular}{|c|c|c|c|c|c|c|c|c|}
\hline \multirow[b]{2}{*}{ No } & \multirow[b]{2}{*}{ Use of credit } & \multicolumn{4}{|c|}{ Rank } & \multirow{2}{*}{$\begin{array}{l}\text { scale } \\
5\end{array}$} & \multirow{2}{*}{$\begin{array}{l}\text { Weight } \\
\text { score }\end{array}$} & \multirow{2}{*}{$\begin{array}{l}\text { Rank } \\
\text { order }\end{array}$} \\
\hline & & 1 & 2 & 3 & 4 & & & \\
\hline 1. & To purchase inputs & 30 & 20 & 11 & 12 & 11 & 298 & $1^{\text {st }}$ \\
\hline 2. & To purchase livestock & 22 & 19 & 8 & 12 & 34 & 268 & $2^{\text {nd }}$ \\
\hline 3. & To purchase household assets & 7 & 6 & 13 & 14 & 44 & 170 & $5^{\text {th }}$ \\
\hline 4. & For social ceremony & 12 & 17 & 21 & 10 & 24 & 238 & $4^{\text {th }}$ \\
\hline 5. & Other household expense & 20 & 24 & 13 & 15 & 12 & 247 & $3^{\text {rd }}$ \\
\hline
\end{tabular}

N.B $=$ the frequency shows multiple responses

The total weight score is the sum of rank order frequencies multiplied respectively by 5 for the first position, 4 for $2^{\text {nd }}$ position, 3 for $3^{\text {rd }}$ position, 2 for $4^{\text {th }}$ position and 1 for the $5^{\text {th }}$ position.

Table 5. Maximum likelihood estimates of logit model and the effects of explanatory variables on the probability of access to formal credit

\begin{tabular}{llllll} 
& B & S.E. & Wald & Sig. & Exp(B) \\
\hline Constant & 1.279 & 1.974 & .420 & .517 & 3.594 \\
SEX & -.673 & .595 & 1.277 & .259 & .510 \\
AGE & -.047 & .019 & 6.255 & $.012^{* *}$ & .954 \\
YEAREDU & .118 & .067 & 3.098 & $.078^{*}$ & 1.125 \\
LANDSIZ & -.305 & .378 & .653 & .419 & .737 \\
INCOME & .019 & .051 & .137 & .712 & 1.019 \\
DISTMKT & .004 & .068 & .003 & .959 & 1.004 \\
DISINS & -.193 & .078 & 6.122 & $.013^{* *}$ & .825 \\
EXTCON & .087 & .107 & .656 & .418 & 1.091 \\
PARTRAIN & .738 & .416 & 3.144 & $.076^{*}$ & 2.091 \\
TLU & .418 & .145 & 8.335 & $.004^{* * *}$ & 1.519 \\
\hline
\end{tabular}

$* * *, * *$ and $*$ significant at $\mathrm{p}<0.01, \mathrm{p}<0.05$ and $\mathrm{p}<0.1$, source own survey $(2017)$

The maximum likelihood estimates of the logistic regression model show that five variables out of ten independent variables were significant factors influencing formal credit use of smallholder farmers.

The age of household head (AGE) found to be a significant factor that influences the households' access to formal credit negatively. As shown in table (4) above the age of the household head negatively affects the farmers' probability of accessing credit at 5\% significance level. A one year increase in the age of the household head results 0.954 increases in the probability of credit access for the household. This due to when the age of farmers become older and older, they couldn't afford credit and unable to deposit their monthly saving since the institution forced the customer to save their savings in every month.

Year of education of household head (YEAREDU) found to a significant factor which affects credit use positively and significantly at less than $10 \%$. As the year of education of household age increase by 1 year, the 
odds in favor of accessing to formal credit use increases by a factor of 1.125.the plausible explanation for this is that education enable the farmers to be more exposure to the external environment and information which helps them easily associate to credit sources.

The distance from home to credit institution (DISINS) was found to negative related and significantly at less than $5 \%$. As the distance between homes to institution increase by 1 kilometer the odd in favor of accessing formal credit decreases by a factor of 2.091. This is because the increment of opportunity cost of time.

Participation in credit related extension package program (PARTRAIN) is another factor, which is significantly related to the dependent variable and that it is significant at $10 \%$ probability level. The odds in favor of accessing to formal credit use increases by a factor of 2.091. If farmers are participating in credit related extension package, they have more information and knowledge regarding to advantage of credit and its role in improving their livelihood through awareness creation.

Number of livestock owned (TLU) is the other most important and highly significant variable that affects the dependant variable at less than $1 \%$ level. As the number of livestock increase by 1 TLU, the odd in favor of accessing formal credit increases by a factor of 1.519. The possible reason is that more livestock owned farmers are less fear and risk taker for borrowing credit since they can simply sell their livestock during credit repayment time.

\section{Conclusion and recommendation}

Based on the findings of the study it can conclude that farmers had used credit for both productive and non productive purpose. Farmers who receive credit related training are better users of formal credit than those who do not receive any training and farmers with higher livestock owned are in a better position to use formal credit than farmers with lower livestock owned. The distance between farmers homestead and credit institution office was the other determining variable due to opportunity cost of time.

Based on the findings of the study the following recommendations are forwarded.

The credit institution has to be increasing its branches and rural credit satellites so that this will decrease the farmer's opportunity cost of time and can also increase elder farmer participation in credit. As it is observed in the study most branches of credit institution are settled in district town. Therefore, increasing the number of offices nearby farmer's village is essential. The credit institution should also provide and diversify credit related trainings on how to manage credit, its usefulness and the way how to use properly and economically. Regularly monitoring and evaluation on how the customer's use their credit is also essential. This can be done through credit extension workers by regularly monitoring and evaluating customers credit management system.

\section{References}

Abebaw A, Yared M C. (2018): Factors Affecting the Use of Information and Communication Technologies for Cereal Marketing in Ethiopia, Journal of Agricultural \& Food Information, DOI: 10.1080/10496505.2018.1438290.

Assifaw L and Adaba G. (2016). Analysis of Factors Affecting Smallholder Farmers' Access to Formal Credit in Jibat District, West Shoa Zone, Ethiopia. International Journal of African and Asian Studies, 25(1):43-53.

CSA (Central Statistical Authority). (2018). Agricultural Sample survey Country Summery, Addis Ababa, Ethiopia: Accessed from www.csa.gov.et/ehioinfo.

Deresse M. and Zerihun A. (2018). Financing challenges of smallholder farmers: A study on members of agricultural cooperatives in Southwest Oromia Region, Ethiopia. Afr. J. Bus. Manage, 12(10):285-293.

Dilayehu D. (2014). The Role of Microfinance Institutions in Accessing Credit and Poverty Reduction in Rural Ethiopia: The Case of Omo Micro Finance Institution in Damot Gale Woreda, Wolaita Zone, MSc Thesis. Hawassa University, Hawassa.

Gizachew A. (2017). Analysis of Determinants of Access to Credit among Smallholder Farmers in Edja District, Guraghe Zone, SNNPR, Ethiopia Department of Agricultural Economics, Wolkite University, Ethiopia. Journal of Economics and Sustainable Development 8 (13): 73-80.

Gujarati D N. (1995).Basic econometrics(3rded.).NewYork:McGraw-HillCo.

Ibrahim A. and Bauer S. (2013). Access to Micro credit and its Impact on Farm Profit among Rural Farmers in Dryland of Sudan, Global Advanced Research Journal of Agricultural Science, 2(3):88-102.

IFAD. (2016). Rural development report 2016: Fostering inclusive rural transformation. Rome, Italy: International Fund for Agricultural Development.

Ololade RA. \& Olagunju F. (2013). Determinants of Access to Credit among Rural Farmers in Oyo State, Nigeria, Global Journals Inc. USA.

Sophia J, Ebimobowei A. and Wisdom S. (2012). An analysis of microfinance and poverty reduction in Bayelsa state of Nigeria. Kuwait chapter of Arabian journal of business and management review, 1(7):38-53.

Yamane T. (1967).Statistics: An introductory analysis.NewYork:Harperand Row. 